\title{
Empowerment of School Committee in Improving Education Service Quality at Public Primary School in Parepare City
}

\author{
Abdul Halik ${ }^{1}$, St. Wardah Hanafie Das ${ }^{2, *}$, Muhammad Aswad ${ }^{3}$, M. Syakir Rady², \\ Muhammad Siri Dangnga ${ }^{1}$, M. Nasir $\mathrm{S}^{1}$ \\ ${ }^{1}$ Institut Agama Islam Negeri (IAIN) Parepare, South Sulawesi, Indonesia \\ ${ }^{2}$ Universitas Muhammadiyah Parepare, South Sulawesi, Indonesia \\ ${ }^{3}$ Universitas Sulawesi Barat, West Sulawesi, Indonesia
}

Copyright $(2019$ by authors, all rights reserved. Authors agree that this article remains permanently open access under the terms of the Creative Commons Attribution License 4.0 International License

\begin{abstract}
School committees in public primary schools have several issues such as the selection and appointment of administrators, partnerships and political will of the principal, procedures for school committee involvement, and increased participation of school committees in carrying out their main duties and functions to improve the quality of education services. The purpose of this study is to build community and school mind-set to work together to improve the quality of education, to establish an inclusive school for school committees, to find strategies to increase the participation of school committees in improving the quality of education services in schools, to find strategies to increase external stakeholder's participation in improving the quality of education service contributions; and to create standard procedure of synergy of school and school committee in improving quality of Public Primary School education service in Parepare City. The research methods used are mixed research (a combination of quantitative and qualitative) and field research. Objects studied are as many as 75 school committees and Public Primary School managers in Parepare City. This research was conducted by collecting data through questionnaire, observation, interview, document study, triangulation, FGD, and workshop. The result of this research is the selection strategy which refers to Permendikbud Number 75 of 2016 and is undertaken democratically; the principal establishes a joint commitment with the school committee to advance the quality, designs the respective authorities and responsibilities, develops a transparent, accountable, and ICT-based administration system, and develops quality standards and operational standards of quality education service procedures.
\end{abstract}

Keywords Committee, School, Standard, Quality, Education

\section{Introduction}

Education units or schools become formal educational institutions that always get a lot of spotlights. Highlights addressed to schools related to the managerial system, character education, quality of education services, to the quality of graduates ${ }^{1}$. Public primary school in Parepare is required to have the quality of education by involving the community actively in supporting the program. The education program at the Public primary school in Parepare will not work effectively without the active involvement of the community in it.

The community is an educational stakeholder who has an interest in the success of education in schools. They are payers or subscribers of education, either through direct financing in the context of school activities and taxes, so that schools should be accountable to the public. At the same time, schools still view the community as someone else or a party outside the school. The school neglected phenomena of the School Committee function, by Ramadan, which are as follows:

1. School Committee is less active.

2. Lack of encouragement from the School Committee to parents of learners and the community.

3. Lack of financial support from the community either individually, group or organization.

${ }^{1}$ Ahmad Salih Alnaser and Mahmoud Khalid, "SERVICE QUALITY DIMENSIONS AND STUDENTS SATISFACTION: A CASE STUDY AT PRIVATE HIGHER EDUCATION INSTITUTIONS,” International Business Research, I.April (2017), 163-75. 
4. The low quality of education is due to the lack of school evaluation and supervision.

Juridically, the demands of community involvement were stipulated in Kepmendiknas number 44 of 2002 on School Committee as the official institution that became the school partner in the implementation of education. Depdiknas said that the School Committee is a non-profit and non-political body or institution, formed based on a democratic meeting by education stakeholders at the educational unit level as a representation of the various elements responsible for improving the quality of education outcomes. Permendikbud Number 75 of 2016 concerning School Committee in article 2 paragraph (2) reads that School Committee functions in improving the quality of education service; and (3), is to carry out its functions in a mutual, democratic, independent, professional, and accountable manner.

The school committee as a partner school organization has the role of one of the school committee's roles in realizing entrepreneurship in the school as a supporting agency, whether in the form of financial, thought or energy in the implementation of education in schools. This context indicates the urgency and relevance of the study of school committee empowerment strategies in order to play an active role in improving the quality of education services in schools, especially in Public Primary School in Parepare.

\section{Problem Statement}

The growing and urgent problem of finding solutions in this paper is the strengthening of the synergy relationship between the school committee and Public Primary School in Parepare, the election and appointment of the school committee; standard work procedure of the school committee political will manage Public Primary School involving school committee role and participate in program quality improvement of education service at Public Primary School in Parepare.

\section{The objective of the Research}

The purpose of this research is to build community and school minds to work together to improve the quality of education through school committees; to build an inclusive school; to make strategies to increase the participation of school committees and other external stakeholders in enhancing the contribution of quality of education services to Public Primary School in Parepare; and to create standard quality and standard procedure of school committee synergy and SDN Public Primary School management in Parepare. The research benefits are the synergy of school and school committees in improving the quality of education, the participation of external stakeholders (business actors) to sponsor educational programs, transparent, accountable, and ICT-based school administration system, and a quality control system under control.

\section{Theoretical Review}

\subsection{School Committee}

National Education System Law number 20 of 2003 Article 1, paragraph 25, reads "School committee/madrasah is an independent institution consisting of parents/guardians of students, school community, and community leaders who care about education." It is affirmed in the Decree of the Minister of Education number 044 / U / 2002, that the school committee is an independent body that accommodates the participation of the community in order to improve the quality, equity, and efficiency of education management in educational units both in preschool education, school education path, and out-of-school education.

The purpose of the establishment of the School Committee as a school community organization is as follows:

a) Accommodate and channel community aspirations and initiatives in giving birth to operational policies and educational programs in educational units.

b) Increase the responsibility and participation of the community in the implementation of education in educational unit.

c) Creating transparent, accountable, and democratic atmosphere and condition in the provision and quality education service in education unit according to Kepmendiknas number: 044 / U / 2002.

Depdiknas in his book Community Participation outlines the seven roles of School Committee on the implementation of schools, namely:

a) Helping to improve the smooth implementation of teaching and learning activities in schools facilities, infrastructure, and technical education.

b) Conducting coaching attitude and behavior of students. Making efforts to strengthen the school in realizing the development and development of piety against Almighty God, early democratic education (national life and state, preliminary education of state defense, citizenship, organization and leadership), skills and entrepreneurship, physical fitness and exercise, power creations and inventions, as well as appreciation of art and culture.

c) Seeking funding sources to help disadvantaged students.

d) Conducting school assessments for curriculum development, both intra and extracurricular and the 
implementation of school management, heads/vice principals, teachers, students, and employees

e) Giving credit to the success of school management.

f) Conducting a discussion of the proposed School Revenue and Expenditure Budget

g) Asking schools to hold meetings for specific interests.

The existence of harmonious relationships between school and society that are accommodated within the School Committee organization is certainly capable of optimizing the participation of parents and the community in advancing education programs, in the form of:

a Parents and communities help to provide educational facilities, provide financial aid as well as the thoughts or suggestions that schools need.

b Parents provide information for the school about the potential that their child has, and

c Parents create an educative home for the child.

It is explained that school committees are very dominant in school planning decisions, especially in decision-making on school budgets (approval of the school budget) and decision-making in school development plans (approval of the school improvement plan) ${ }^{2}$ ]. The school committee as a body of consideration has three functions: to provide consideration in school planning, implementation of educational programs, and management of educational resources.

The school committee is an institution responsible for determining the vision, mission and objectives of the school, establishing and monitoring the annual operating budget, using, managing and evaluating, and determining and reviewing policies and practices to support students' achievement. The role of the School Committee cannot stand alone, but rather the interrelated role of one role with other roles. It can be explained as follows:

a Advisory agency in the determination and implementation of education policy in educational unit.

b Supporters (supporting agency) either tangible financial, thought, or labor in the implementation of education in educational units

c Mediator between government (executive) and with society in educational unit.

School committees have a very significant role in advancing schools, especially in primary schools. Society is present through the school committee and together with the manager of the education unit to design the school building, in terms of vision-mission, infrastructure, and education and pedagogy programs. School synergy and school committees are the right solutions to improve the

\footnotetext{
2 Joseph I. Zajda dan David Thenuwara Gamage, Decentralisation, school-based management, and quality (Springer, 2009), VII.
}

quality of education and learning programs.

\subsection{Quality of Educational Service}

Educational institutions formed by the community to meet the needs of many people. Educational institutions are public organizations in order to provide quality services necessary changes in resources owned, in the form of improvement of service tools and maximize the role of existing servants ${ }^{3}$. Steps that need to be taken by educational institutions to improve these services are to optimize the ability of human resources and improve facilities and infrastructure that support the smoothness of education services.

Educational institutions are engaged in services that demand quality and stakeholder satisfaction ${ }^{4}$.

Service is an act whereby a person or group offers to another group something essentially intangible and whose production is related to or unrelated to the physical product ${ }^{5}$. Educational services are the psychological aspects of cognitive, affective, psychomotor, social, and spiritual, whose indicators are positive attitude change and stakeholder satisfaction.

There are five dominant factors or the determinant of the quality of service, which ultimately becomes the determinant of the level of satisfaction ${ }^{6}$. The five factors that when applied to educational institutions are as follows. The first is the reliability namely the ability of teachers or lecturers to provide services in accordance with the promised, reliable, accurate, and consistent ${ }^{7}$. The second is responsiveness, namely the willingness of employees and employers or institutional owners to assist customers and provide services quickly and meaningfully as well as the willingness to hear and address complaints filed by consumers, such as the provision of appropriate means to ensure the right process. The third is assurance that is in the form of an employee's ability to generate confidence and trust in promises that have been presented to consumers, such as promises in the promotion. The fourth is empathy that is the willingness of teachers, lecturers, employees and

\footnotetext{
${ }^{3}$ Azleen Ilias, Mohd Zulkeflee, dan Abd Razak, "Service Quality and Student Satisfaction : A Case Study at Private Higher Education Institutions," International Business Research, 1.April 2018 (2009), 16375 < https://doi.org/10.5539/ibr.v1n3p163>.

${ }^{4}$ M S Son dan H I Hamdy, "Managing Service Quality of High School Delivery : Evidence from Kuwait," International Journal of Education, 7.2 (2015), 67-94 <https://doi.org/10.5296/ije.v7i2.5803>.

${ }^{5}$ Kotler Philip, Marketing Management, International Edition (Prentice Hall, Pearson Education International, Upper Saddle River, New Jersey, 2003).

${ }^{6}$ Gencay \& Barış Aşııgil İncesu, "An Evaluation of the Relationship between Service Quality in Primary Education and Parent Satisfaction," International Journal of Business and Management, 7.18 (2012), 92-98 $<$ https://doi.org/10.5539/ijbm.v7n18p92>.

7 Teo Boon, Mohd Shukur, dan Ahmad Bassim, "Evaluation of Service Quality of Private Higher Education using Service Improvement Matrix," Procedia - Social and Behavioral Sciences, 224.August 2015 (2016), 132-40 <https://doi.org/10.1016/j.sbspro.2016.05.417>.
} 
managers to care more about giving personal attention to subscriptions, for example, teachers, lecturers, employees or managers should try to place themselves as learners, parents, and customers ${ }^{8}$. If the customer complains then a solution must be sought to reach a harmonious agreement by showing genuine caring. The fifth, which is tangible, is the appearance of physical facilities, equipment, and various communication materials.

Educational customer satisfaction is the main orientation of education program implementation in school $^{9}$. Customer satisfaction is determined by two cognitive variables i.e. expectation at the time before purchase (pre-purchase expectation) that is a belief about anticipated performance of a service product and "disconfirmation" that is the difference between pre-empirical difference and perception from post-purchase prescription " ${ }^{10}$. Schools of public interest depart from an expectation of the school's promoted performance and the perceived reality of stakeholders after becoming a customer.

In maintaining the quality of service at educational institutions, what should be noted is the attribute of continuous service quality improvement, namely:

a Timeliness of service;

b Accuracy of service;

c Courtesy and hospitality in providing service;

d Responsibility relates to acceptance of suggestions, and handling customer complaints;

e Completeness of availability of supporting facilities;

f Variation of service model. Students may choose time for tutoring;

g Ease of service;

h Personal service, relating to the flexibility of special handling of a group of customers requesting special handling;

i Convenience in obtaining services, relating to the location of educational institutions, space for service, and availability of information;

j Other service support attributes such as environmental infrastructure of educational institutions ${ }^{11}$.

Cleanliness of study rooms, canteen facilities, and health services. Service quality standards can be seen from the internal aspects of the school and external stakeholder

\footnotetext{
${ }^{8}$ Ernest Lim, Kok Seng, dan Tan Pei Ling, "A Statistical Analysis of Education Service Quality Dimensions on Business School Students , Satisfaction,” International Education Studies, 6.8 (2013), 136-46 <https://doi.org/10.5539/ies.v6n8p136>.

9 Atif Manzoor, “Assessment of Service Quality in Public Secondary Schools of Punjab Based on ServQual Quality Determinants,” Industrial Engineering Letters, 8.2 (2018), 9-19.

${ }^{10}$ U. Maman Rubaman, "Mengukur Kepuasan Masyarakat Terhadap Pelayanan Pendidikan,” Jurnal FISIP: MADANI, 7.1 (2012).

${ }^{11}$ Eti Rochaety, “Sistem Informasi Manajemen Pendidikan, PT,” Bumi Aksara, Jakarta, 2005.
}

aspects. $^{12}$

\section{Research Method}

\subsection{Research Paradigm}

This research used qualitative research ${ }^{13}$ which assesses the objects of study and activities in the field that occurs in a natural context and researchers attempt to understand the meaning and interpret the phenomena that occur during the field. Committee and public primary school studied were 75 in Parepare City.

\subsection{Approach}

The approach of this research is phenomenology, specifically research that observes about the phenomenon that occurs in human life where the researchers tried to enter into the conceptual world of subjects who studied in such a way that they understand what and how a sense developed by them around events in daily life. This approach examines in depth the concepts of schools, organizational culture, vision and mission, and work programs that will be implemented.

\subsection{Technique of Data Collection}

Data collection can be done in various settings, various sources, and various ways. This research is descriptive qualitative, then the data is collected by using several methods, namely: participant observation, in-depth interview, and documentation, triangulation, and focus group discussion.

\subsection{Technique Data Analysis}

Qualitative data analysis in this research is done at the time when data collection take place and after the completion of data collecting in a certain period. Data analysis technique used in this research is an approach applied by ${ }^{14}$ that is done in three activity flow which is one unity (interrelated), that is; (1) word reduction; (2) data presentation; (3) drawing conclusions/verification. Qualitative analysis techniques are carried out for data taken from the field. Activity in qualitative data analysis is done interactively and run continuously until completion, so the data is saturated (complete).

\footnotetext{
${ }^{12}$ Hulya \& Gokmen Dagli Senol, "Increasing Service Quality in Education : Views of Principals and Teachers," EURASIA Journal of Mathematics Science and Technology Education, 8223.8 (2017), 4857$71<$ https://doi.org/10.12973/eurasia.2017.00969a>.

${ }^{13}$ Norman K. Denzin dan I. S. Lincoln, "Handbook of qualitative research (terj. Dariyatno; Badrus Samsul Fata; Abi; John Rinaldi),” Yogyakarta: Pustaka Pelajar, 2009.

${ }^{14}$ Matthew B. Miles dan A. Michael Huberman, Qualitative data analysis (Sage Newbury Park, CA, 1985).
} 


\section{Results}

School committee in education unit elementary school level in Parepare City is 75 units. Based on the results below, all primary schools have education and education committees at the Education Office Parepare. The school committee in its interaction with the school is quite dynamic. There is a teacher as active as the principal who is open and asks to cooperate. Some school teachers were initially proactive but after the principal was transferred, the school committee became passive. There are schools that are not active in school because of busy committee school officials. There are school committees that attend at certain times in the school such as acceptance of new learners, students' observations, class increases, religious holidays, and so forth.

The school committee is part of the school. A school without school committee will not be able to run well in achieving goals. The school seeks to achieve its goals but is not supported by strong bases and foundations. Schools come from the community, work with the community, and return to the community. The concept inspired some of the school committee members in Parepare by 'donating' their time and energy to participate in building schools. The people of Kota Parepare are more likely to care about formal education so that educational programs in schools often get criticism from the public.

The facts on the ground indicate that there are school committees that actively participate in the school, realizing how schools need community attendance. Active school committees sometimes come to school on school mornings, monitor learners entering school gates, help schools break down traffic congestion around schools, control school canteens, monitor students who are late or do not attend classes, and arranging schoolyards, and so on. The action of the school committee reaped praise from the government of Parepare City and from the community.

School committees that are less even not actively cooperating with schools, based on observations and field interviews, are caused by several factors:

a The lack of support from schools, principals, and teachers to bring school committees together to solve school problems;

b Inactivity of school committees is caused by conflicts (miscommunication) between fellow administrators or to school managers;

c Lack of budget support, both from schools and from communities, so school committees do not make work programs due to budgetary factors;

d School committees are not active in performing their main duties and functions because of their preoccupation with their respective professions;

e The low resources of the school committee so there is no initiation and motivation to undertake programs that can contribute to improving the quality of education services in schools.
The problems of the school committee mentioned above are quite hampering the improvement of the quality of education in schools. Public elementary schools in Kota Parepare are in urgent need of synergy and contribution from the community through school committees to improve the trust and quality of education services.

The problems in the school committee are starting from the election and appointment process. The selection of school committees is often used as a practical political moment so that although democratically practiced, commitment and professionalism are sometimes ignored. The process of selecting school committees is often colored by riots or deadlocks because personal interests dominate them more. The ambition of becoming a school committee is often an obstacle in finding trustworthy and willing to work figures.

The existence of Permendikbud No. 75 of 2016 on the school committee becomes a new beginning for the selection process of candidates and election procedures. Although it is still in the plains of socialization, the public elementary school has got an understanding of the importance of referring to Permendikbud in order to work optimally. The affirmation of Permendikbud referred to in article 4, paragraph 3, declared that school committee members cannot come from the educator and education personnel of the school concerned, the concerned school organizer, the village administration, the head of the sub-district and district level organizations, DPRD members or politicians, and local officials in education. The existence of the limits of the school committee board becomes a debate later because many are interested in certain interests.

Parepare City is a community that cares about education, usually with strong influence to get recommendations from the community to become the school committee. On the one hand, influential school committees will have an impact on funding support for education management in schools. On the other hand, schools are often used for the personal interests of the school committee chairman. The new Permendikbud provides restrictions for school committees not to engage in activities such as selling textbooks, uniforms, and others; not levy the parents of learners, injure the integrity of the selection of new learners, undertake programs that harm school integrity, deal with the economic benefits of its position, utilize school assets for personal gain, engage in practical political activities, and perform acts outside or exceed their powers.

The existence of new Permendikbud encourages schools to have the independence to assign members of the school committee. The results of field observations indicate that there are some schools that conspire against the determination of school committee members; for example, the school assigns members of school committees from colleagues or who can be invited to compromise in the management of education. But there are also schools that 
invite participants who attend the meeting to propose who is assigned to be a member of the school committee. Various kinds of attitudes and ways of schooling in selecting and assigning members of the school committee, of course, are in their authority because of the directive of Permendikbud number 75 of 2016.

The above description reaffirms that the activeness and participation of school committees depend on the political will of the school organizers. Political will is meant by the school officials' awareness and willingness on the importance of school committee presence, school committee members must have resources and commitment, school organizers looking for candidates for school committee members who have access and partnership networks, and so on. Schools are important to believe that the quality of education can be achieved with the intensity of school committees in participating. Participation and dedication of school committees can be an indicator of school organizers' considerations.

The data in the field that is compiled by researchers suggests that active school committees indicate an inclusive (open), visionary, professional, and democratic school organizer. The principal, who is open to the deficiencies and weaknesses of the school, encourages the principal to ask for help. Visionary school principals certainly involve school committees in the face of future challenges. The principal of a professional school judges that there is a certain area that the school cannot accept the participation of the school committee. Democratic school committees are always accommodative and representative in policymaking. The description is urgent for all heads of public elementary schools in Parepare City, so the school committee is empowered optimally.

School committees participating in schools need to receive a response and appreciation from the school. School committees perform their main tasks and functions based on existing regulations; they need only sharpening and affirmation from the school. Important schools provide an inclusive space to school committees to grow creativity and innovation in contributing to the school. If the school committee finds the right momentum to work, then it will work optimally and without taking into account how much it will cost.

At the public elementary school in Parepare City, the school committee has done a lot of things. One informant stated that "we do a noble task in school, our children are nurtured and mentored, so it is our obligation to control, provide feedback, find sponsors if there is activity. All we do are due to the awareness of generational education responsibilities".

Another informant stated that: "as a school committee, it should be present to help the school solve its problems based on its main task and function. I am at a school discussion, whether the principal, or the teacher, or the employee ". School committees like this are expected by school organizers to run educational programs. School committees that are pro-active in schools will have an impact on the effectiveness of educational programs. School committees can work and advise on specific programs in the school, for example at the admission of new learners, the orientation of new learners, religious activities, and so forth.

School organizers are required to provide transparent and accountable information and clarification to the public. The school committee can be a mediator between school and community. The informant from the school committee stated that "I am a school committee in one of the public primary school in Parepare City; my most frequent task is a school spokesperson to the community or vice versa. Sometimes there is a community-related school policy, so I often explain the importance of community participation, and sometimes community feedback to schools, and I tell the school that it is important to consider.

"The researcher found the informants in the field who gave different information. The informant stated that:" We as committee members of the school, we often come to school only to monitor the conditions of education and services to the students. We monitor our children if anyone wandering around, we wondered whether we were learning, etc. We just monitored and did not participate in intervening or harassing friends at school while working. "The school committee's description is a form of community participation in the education and learning process at school.

Other facts are found in the field and this happens a lot in schools, and school committees are only present at school if invited by the school. The school seems to regard the existence of the school committee as a school partner in improving quality and solving educational problems. School committees are considered passive for educational programs in schools and schools also do not demand school committees to be pro-active. Both sides are passive in working together to synergize on educational and learning tasks at school.

Informant's information from the school committee stated that: "we are not very active in school because we do not know what to do, where the limits of our authority. We are often cautious because there is no reference to us in doing activities at school ". The statement confirms that the importance of schools with school committees establishing quality standards and quality procedures as a reference in carrying out tasks at school.

The findings in the field show that public primary schools in Parepare have no quality document that became the reference of the school committee in carrying out its main duties and functions. The existence of quality documents in which there are quality standards and quality standard procedures so the school and school committees can synergize effectively because there is already the authority of each and have a clear target achievement and firm. The clarity of the direction and purpose of every education and learning program in the school, then all 
parties can share the roles and responsibilities for the achievement of that goal.

\section{Discussion}

School, as a public organization, is owned by the community, and works for the community; it takes the trust of the community in carrying out educational and learning tasks. Community trust can be established through the presence of the school committee (as a representation of parents/parent learners) which can be a mediator, advisors, and supporters of educational programs at the school. Schools are advanced and qualified if they have the support and trust of the community.

Public elementary schools in Kota Parepare urgent have a commitment to partnership and synergy to the school committee. Therefore, the school should be objective and rational in selecting and assigning members of the school committee. The selected school committee is a representation of the community and has a commitment and dedication in carrying out its main duty, as in Permendikbud. number 75 of 2016.

Permendikbud number 75 of 2016 on School Committees in Article 3 paragraph 1 states that the task of the school committee is:

1) Providing consideration in the determination and implementation of related education policies:

2) School policies and programs;

3) School Budget Income and Expenditure Plan / Work Plan and School Budget

4) School performance criteria;

5) Criteria for education facilities in schools; and

6) Criteria for school cooperation with other parties.

7) Raising funds and other educational resources from the community, both individuals/ organizations/business world/industry and other stakeholders through creative and innovative efforts;

8) Supervising education services in schools in accordance with the provisions of legislation; and

9) Following up on complaints, suggestions, criticisms, and aspirations of learners, parents/guardians, and the community and the results of school committee observations on school performance.

The purpose of the school committee is to accommodate and channel community aspirations and initiatives in operational policies. Consumers who must be served and very concerned are learners and their parents. If the school committee plays an active role in channeling the aspirations of learners, parents and the community then the results will be highly qualified. Therefore, school committees are required to participate in developing the quality of education in schools. The problem here is that schools should open up creative spaces for school committees to run their duties, and school committees must have the dedication and commitment to help schools implement quality education services.

School committees with awareness and commitment to help schools will have implications for the quality of education in schools. The school can work optimally because it is backed up by the school committee in carrying out its duties. Therefore, the importance of quality documents in each school serves as a reference in carrying out the main tasks and functions of the school committee. With clear reference and measurable targets, school committees can work maximally, do not interfere with the main tasks of the school, and there are limits of work area and authority and all measurable implementation of work programs.

\section{Conclusions}

The description of the results of research and discussion mentioned above, it can be concluded, namely:

1. The public elementary school organizer in Parepare is urgent to be open and aware of the importance of school committee participation in assisting in the school quality improvement program.

2. The organizer of public elementary schools in Parepare are required to be objective, rational, professional, and democratic in choosing and appointing school committee members, and the main reference for determining the criteria of school committee members is Permendikbud. number 75 of 2016.

3. The organizer of public elementary school is required to have political will to give legitimacy to the school committee in carrying out its main duties and functions, to offer space and freedom of the school committees to create and innovate based on the importance of improving the quality of education services in schools.

4. The organizer of public elementary schools together with the school committees jointly develop standards and standard quality procedures as a basis and reference in implementing quality education service improvement programs at public elementary schools in Parepare.

\section{REFERENCES}

[1] Zajda, J. I., \& Gamage, D. T. (2009). Decentralisation, school-based management, and quality (Vol. 7). Springer.

[2] Philip, K. (2003). Marketing Management, International Edition. Prentice Hall, Pearson Education International, Upper Saddle River, New Jersey. 
[3] Rubaman, U. M. (2012). Mengukur Kepuasan Masyarakat Terhadap Pelayanan Pendidikan. Jurnal FISIP: MADANI, $7(01)$.

[4] Rochaety, E. (2005). Sistem Informasi Manajemen Pendidikan, PT. Bumi Aksara, Jakarta.

[5] Denzin, N. K., \& Lincoln, I. S. (2009). Handbook of qualitative research (terj. Dariyatno; Badrus Samsul Fata; Abi; John Rinaldi). Yogyakarta: Pustaka Pelajar.

[6] Miles, M. B., \& Huberman, A. M. (1985). Qualitative data analysis. Sage Newbury Park, CA. Retrieved from http://researchtalk.com/wp-content/uploads/2014/01/Miles -Huberman-Saldana-Drawing-and-Verifying-Conclusions. pdf 